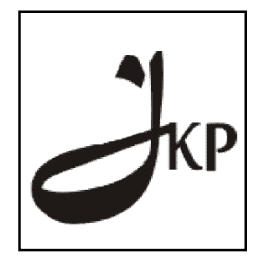

Jurnal Konseling dan Pendidikan

ISSN Cetak: 2337-6740 - ISSN Online: 2337-6880

http://jurnal.konselingindonesia.com

Volume 3 Nomor 3, November 2015, HIm 33-41

Info Artikel:

Diterima 12/10/2015

Direvisi 11/11/2015

Dipublikasikan $28 / 11 / 2015$

\title{
UPAYA MENINGKATKAN HASIL BELAJAR DAN KEAKTIFAN SISWA PADA MATA PELAJARAN IPS MELALUI METODE SOSIODRAMA DAN MEDIA GAMBAR KOMIK PADA SISWA KELAS I SD NEGERI 45 PULAU KARAM KECAMATAN KOTO XI TARUSAN TAHUN PELAJARAN 2012/2013
}

\section{GANESTI}

Abstrak

Penelitian ini didasarkan pada pembelajaran yang kurang mengajak siswa berfikir logis dan hanya mementingkan pemahaman dan hafalan.Keadaan ini mengakibatkan siswa jenuh belajar.Tujuan penelitian ini untuk mendapatkan gambaran pelaksanaan pembelajaranmenggunakan metode sosiodrama dan media gambar komik untuk pembelajaran tentang anggota keluarga pada siswa kelas I SD. Penelitian ini merupakan penelitian Tindakan kelas yang dilaksanakan sebanyak dua siklus.Penelitian dilaksanakan pada SD Negeri 45 Pulau Karam, Kecamatan Koto XI Tarusan Kabung. Subjek penelitian siswa kelas 1 sebanyak 32 orang yang terdiri dari 21 siswa laki-laki dan 11 siswa perempuan. Berdasarkan analisis hasil evaluasi yang telah dilaksanakan, sebelum adanya perbaikan pembelajaran (pra siklus) tercatat 18 siswa dari 32 siswa yang mendapat nilai kurang dari 60 dengan nilai terendah 35 dan nilai rata-rata 57,58. Namun setelah adanya perbaikan pembelajaran siklus I, siswa yang mencapai nilai 60 semakin bertambah dengan rata-rata kelas 62,32 pada siklus II siswa yang mencapai nilai diatas 60 semakin bertambah dengan rata-rata kelas 74,03. Sebelum diadakan perbaikan pembelajaran (pra siklus) Ilmu Pengetahuan sosial, tingkat aktivitas dan keberanian siswa tergolong rendah yaitu hanya $77 \%$.Aktifitas pembelajaran masih didominasi oleh guru. Namun setelah perbaikan pembelajaran siklus I, kegairahan dan keberanian siswa dalam pembelajaran meningkat menjadi $86 \%$.Pada siklus II aktivitas siswa semakin bertambah menjadi $95 \%$. Penelitian ini membuktikan bahwa metode sosiodrama sangat tepat digunakan untuk meningkatkan pemahaman materi pelajaran IPS pada siswa SD kelas I.

Keyword: Metode Sosiodrama, Media Gambar Komik;Aktivitas siswa, Hasil Belajar IPS; SD.

Copyright (C) 2015 IICET (Padang - Indonesia) - All Rights Reserved

Indonesian Institute for Counseling, Education and Theraphy (IICET)

\section{PENDAHULUAN}

Upaya meningkatkan mutu pendidikan dan kualitas sumber daya manusia khususnya di sekolah dasar(SD) sangat bergantung pada kualitas proses pembelajaran yang dikelola oleh guru. Guru memegang peranan penting dan dituntut lebih profesional dalam meningkatkan kinerjanya. Proses perbaikan pembelajaran merupakan sebuah komitmen yang harus dilakukan guru dalam meningkatkan mutu pembelajaran di dalam kelas.Keberhasilanproses pembelajaran ditandai dengan dikuasainya materi pelajaran oleh siswa yang diukur melalui tes atau ujian baik berupa tes formatif, Ulangan tengah semester (UTS) maupun ulangan umum semester (UUS).

Kenyataan yang ada pada setiap akhir proses pembelajaran hasil belajar siswa kurang memuaskan. Oleh karena itu perbaikan proses pembelajaran mutlak dilaksanakan oleh setiap guru. Setiap kegiatan pembelajaran mempunyai tujuan yang sama yaitu meningkatkan prestasi belajar siswa. Demikian juga pada pembelajaran di SDN 45 Pulau Karam Kecamatan Koto XI Tarusan terutama pada mata pelajaran Ilmu Pengetahuan Sosial. Guru menginginkan adanya peningkatan prestasi bagi tiap siswa-siswinya.

Guru harus berusaha melakukan perbaikan-perbaikan dalam proses pembelajaran. Perbaikan dapat dilakukan pada komponen-komponen pembelajaran.Komponen-komponen dalam pembelajaran berhubungan dengan cara mengorganisasikan materi, metode yang ditetapkan, media yang digunakan dan sebagainya. Selain komponen-komponen pokok yang ada dalam kegiatan belajar mengajar, juga ada faktor lain yang ikut mempengaruhi keberhasilan belajar siswa. Seperti motivasi siswa, lingkungan rumah yang kondusif, kesehatan dan lain-lain.Melalui kegiatan pembelajaran guru dapat membantu siswa untuk mengembangkan kemandirian, 
kepercayaan diri, meningkatkan kemampuan akademis dan rasa antusias untuk menyelesaikan tugas-tugas selanjutnya dalam suasana kelas yang menyenangkan dan aman.

Guru perlumelakukan inovasi-inovasi dalam pembelajaran seperti tidak mendominasi kegiatan pembelajaran, menggunakan multi metode, dan menggunakan media-media pembelajaran. Guru sebagafasilitator harus mampu menciptakan situasi kondusif, memberikan motivasi dan membimbing siswa agar dapat mengembangkan potensi dan kreativitasnya melalui kegiatan pembelajaran. Guru juga dituntut dapat melakukan perubahan proses pembelajaran agar situasi belajar mengajar menjadi lebih baik, sehingga hasil yang dicapai dapat meningkat.

Mencermati keberadaan SD Negeri 45 Pulau Karam khususnya di kelas I terdapat setengah lebih jumlah siswa yang mengalami kesulitan belajar pada mata pelajaran Ilmu Pengetahuan Sosial.Guru lebihcenderung teksbook (berorientasi pada buku teks), hanya memberikan pengetahuan kepada siswa.Siswa kurang diajar untuk berfikir logis dan hanya mementingkan pemahaman dan hafalan.Hal ini membuat siswa merasa jenuh untuk belajar, sehingga siswa menganggap pembelajaran IPS cukup sulit.Jika siswa sudah jenuh belajar, maka mereka mencari kegiatan-kegiatan yang menyenangkan.Kegiatan tersebut seperti mengobrol dengan teman atau bermain.

Guru harus dapat menciptakan proses pembelajaran yang menyenangkan dengan memilih metode dan media pembelajaran yang bervariatif. Siswa yang mengikuti pembelajaran dengan menyenangkan maka siswa akan terlibat aktif untuk belajar.Salah satu metode pembelajaran yang dapat digunakan pada mata pelajaran IPS adalah metode sosiodrama dan media pembelajaran berupa gambar komik.Metode sosiodrama bertujuan memberikan gambaran mengenai bagaimana orang bertingkah laku dalam situasi social tertentu dan belajar menghayati keadaan (Abu Ahmadi:2005:82). Salah satu manfaat dari media pembelajaran adalah memperbesar perhatian siswa terhadap pembelajaran yang dilaksanakan (Arsyad, Ashar:2002:15).

Berdasarkan paparan di atas penulis tertarik untuk melakukan penelitian tindakan kelas menggunakan metode pembelajaran sosiodrama dan media pembelajaran bergambar komik. Rumusan penelitian ini bagaimanakah pembelajaran menggunakan metode sosiodrama dan media gambar komik untuk pembelajaran tentang anggota keluarga pada siswa kelas I SD. Penelitian ini bertujuan untuk mendapatkan gambaran pelaksanaan pembelajaranmenggunakan metode sosiodrama dan media gambar komik untuk pembelajaran tentang anggota keluarga pada siswa kelas I SD. Gambaran pelaksanaan pembelajaran dilihat dari hasil belajar siswa dan aktivitas belajarnya.

\section{METODOLOGI PENELITIAN}

Penelitian ini menggunakan metode penelitian tindakan kelas (action research).Siklus penelitian ini sebanyak 2 kali.Siklus penelitian tindakan kelas ini merujuk dari pendapat Ritawati dan Yetti (2007) dan Rochiati (2007) dapat dilihat di bawah ini.

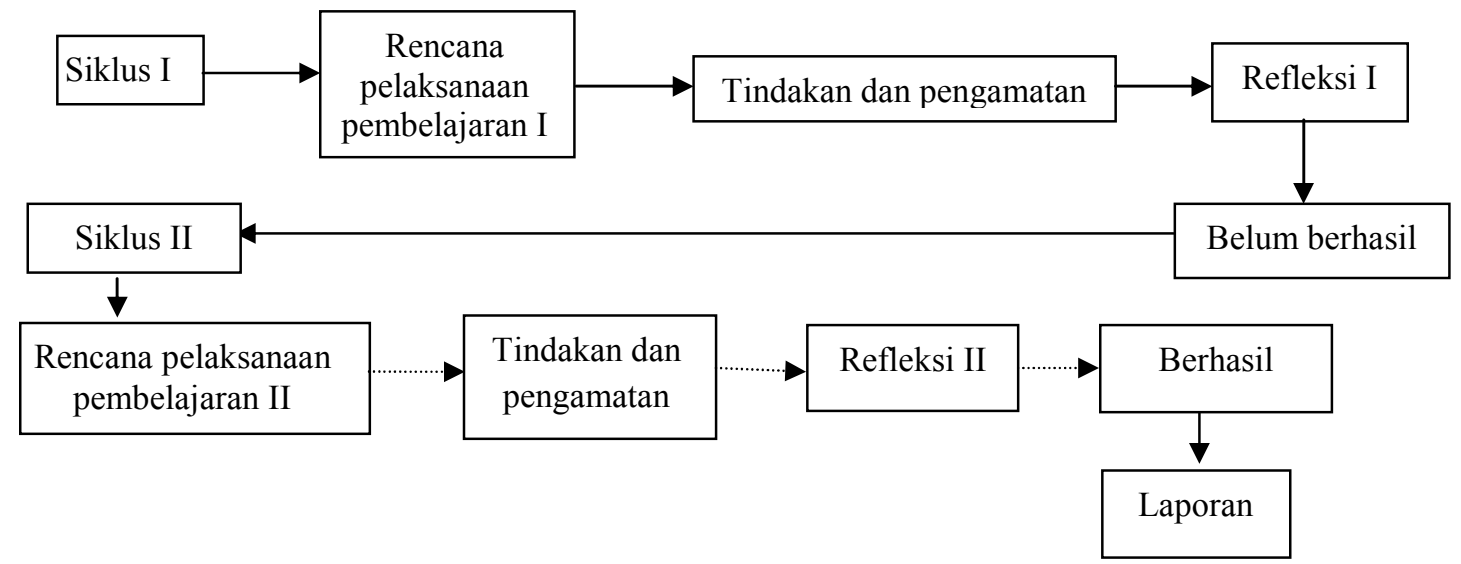

Pembelajaran dilaksanakan di kelas I SD Negeri 45 Pulau Karam, Kecamatan Koto XI Tarusan Kabupaten Pesisir Selatan.Jumlah siswa kelas I ada 32 Siswa-Siswi, terdiri dari 21 siswa laki-laki dan 11 siswa perempuan.Pelaksanaan penelitian setiap siklus dapat dijelaskan berikut ini. 


\section{Pra Siklus}

\section{Perencanaan}

1. Meminta ijin dari Kepala Sekolah

2. Membuat RPP

3. Menghubungi teman sejawat

\section{Pelaksanaan}

Langkah-langkah pembelajaran untuk mata pelajaran IPS sebagai berikut;

a. Pra KBM

- Guru dan siswa Berdoa Bersama

- Guru Mengabsen siswa

- Guru menyiapkan Alat - alat Pelajaran

- Guru mengkondisikan siswa agar siap menerima pelajaran

b. Kegiatan Awal

- Apersepsi

- Mengajukan Pertanyaan yang mengarah pada materi :

Contoh :Ada berapa jumlah Anggota Keluarga kalian? Ayo Hitung? Siapa saja mereka?

c. Kegiatan Inti

- Secara klasikal siswa memperhatikan penjelasan dari guru tentang anggota-anggota keluarga

- Siswa melakukan tanya jawab tentang anggota-anggota keluarga

- Setelah melakukan diskusi kelompok, siswa dapat menunjukkan anggota-anggota keluarga

d. Kegiatan akhir

- Dengan bimbingan Guru siswa menyimpulkan materi

- Siswa melaksanakan Evaluasi

Refleksi

- guru mengoreksi hasil evaluasi siswa

Melalui refleksi dan diskusi tentang hasil pembelajaran Ilmu Pengetahuan Sosial hasilnya masih jauh dari yang diharapkan, atau nilainya jauh dari KKM yang ditentukan (KKM IPS adalah 60). Selain itu juga aktivitas yang terlihat belum maksimal karena lebih dari $50 \%$ jumlah siswa masih terlihat pasif dalam proses pembelajaran. Melihat kenyataan yang sedemikian rupa, maka penulis perlu melaksanakan perbaikan siklus I.

\section{Siklus I}

\section{Perencanaan}

Membuat perencanaan pembelajaran dengan berpedoman pada hasil belajar pra siklus. Rencana pembelajaran yang dibuat yaitu guru menjelaskan materi, siswa membaca komik, tanya jawab dengan siswa,melakukan sosiodrama tentng peran anggota keluarga.

\section{Pelaksanaan}

\section{Pra KBM}

$>$ Guru dan siswa berdoa bersama

$>$ Guru Mengabsen siswa

$>$ Guru menyiapkan Alat - alat Pelajaran

$>$ Guru mengkondisikan siswa agar siap menerima pelajaran

Kegiatan Awal

$>$ Apersepsi dengan mengajukan Pertanyaan yang mengarah pada materi, sepertiAda berapa jumlah Anggota Keluarga kalian? Ayo Hitung? Siapa saja mereka?

\section{Kegiatan Inti}

$>$ Secara klasikal siswa memperhatikan penjelasan dari gurutentang anggota keluarga

$>$ Secara individual siswa membaca komik tentang anggota-anggota keluarga

$>$ Guru bertanya kepada siswa tentang komik yang dibaca.

$>$ Siswa melakukan sosiodarama tentang peran anggota keluarga

\section{Kegiatan akhir}

$>$ Guru membimbing siswa menyimpulkan materi 
$>$ Siswa melaksanakan Evaluasi

$>$ Guru mengoreksi hasil evaluasi siswa

\section{Refleksi}

Melalui refleksi dan diskusi tentang hasil perbaikan pembelajaran IPS siklus I pada dasarnya sudah menunjukkan adanya peningkatan yang signifikan, tetapi berdasarkan analisis, hasil latihan kebanyakan siswa masih keliru dalam menunjukkan peran kakak dan adik.Untuk itu penulis memandang masih perlu melaksanakan perbaikan siklus II.

\section{Siklus II}

\section{Perencanaan}

Perencanaan yang dibuatguru lebih ditekankan mengenai sosiodrama peran kakak dan adik.

\section{Pelaksanaan}

Langkah-langkah perbaikan pembelajaran siklusII sama dengan langkah-langkah perbaikan pembelajaran pada siklus I, ditekankan pada sosiodrama tentang peran kakak dan adik.

\section{Pra KBM}

$>$ Guru dan siswa berdoa bersama

$>$ Guru mengabsen siswa

$>$ Guru menyiapkan aat - alat Pelajaran

\section{Kegiatan Awal}

$>$ Mengajukan Pertanyaan yang mengarah pada materi yaitu Ada berapa jumlah Anggota Keluarga kalian?Ayo Hitung?Siapa saja mereka?

\section{Kegiatan Inti}

$>$ Secara klasikal siswa memperhatikan penjelasan dari gurutentang anggota keluarga

$>$ Secara individual siswa membaca komik tentang peran anggota-anggota keluarga

$>$ Guru bertanya kepada siswa tentang komik yang dibaca.

$>$ Siswa melakukan sosiodarama tentang peran kakak dan adik

\section{Kegiatan Akhir}

$>$ Guru membimbing siswa menyimpulkan materi

$>$ Siswa melaksanakan Evaluasi

$>$ Guru mengoreksi hasil evaluasi siswa

\section{Refleksi}

Melalui refleksi dan diskusi tentang hasil perbaikan pembelajaran IPS siklus II pada dasarnya sudah menunjukkan adanya peningkatan yang signifikan, maka pembelajaran pada siklus II dapat dikatakan tuntas.

\section{HASIL DAN PEMBAHASAN PENELITIAN \\ HASIL PENELITIAN}

Penulis melakukan penelitian sebanyak dua siklus yaitu siklus I dan siklus II.Penelitian pada masingmasing siklus mencakup penilaian hasil belajar siswa sertapenilaian aktivitas guru dan siswa selama pelaksanaan pembelajaran.

a. Hasil Belajar Siswa

Hasil tes formatif dari 32 siswa kelas Isemester ganjil SD Negeri 45Pulau Karam mata pelajaran Ilmu Pengetahuan sosial dengan kompetensi Dasar “ Mendeskripsikan Anggota-Anggota Keluarga ” pra siklus, siklus I, siklus II dapat dilihat dari tabel berikut. 
Tabel 1

Penilaian Hasil Belajar Siswa

\begin{tabular}{|c|c|c|c|c|c|}
\hline No & Nama Siswa & Pra Siklus & Siklus I & Siklus II & Ket \\
\hline 1 & AEP & 40 & 50 & 75 & \\
\hline 2 & $\mathrm{AY}$ & 45 & 55 & 80 & \\
\hline 3 & $\mathrm{AR}$ & 40 & 50 & 75 & \\
\hline 4 & AS & 45 & 55 & 80 & \\
\hline 5 & $\mathrm{AR}$ & 50 & 60 & 85 & \\
\hline 6 & $\mathrm{CA}$ & 50 & 60 & 85 & \\
\hline 7 & Drs & 40 & 50 & 75 & \\
\hline 8 & $\mathrm{DR}$ & 50 & 60 & 85 & \\
\hline 9 & DM & 55 & 65 & 90 & \\
\hline 10 & DG & 45 & 55 & 80 & \\
\hline 11 & DPW & 40 & 50 & 75 & \\
\hline 12 & DK & 50 & 60 & 85 & \\
\hline 13 & EW & 55 & 65 & 90 & \\
\hline 14 & ES & 60 & 70 & 95 & \\
\hline 15 & $\mathrm{EY}$ & 60 & 70 & 95 & \\
\hline 16 & ED & 50 & 60 & 85 & \\
\hline 17 & EW & 60 & 70 & 95 & \\
\hline 18 & ED & 55 & 65 & 90 & \\
\hline 19 & ES & 40 & 50 & 75 & \\
\hline 20 & HS & 50 & 60 & 85 & \\
\hline 21 & $\mathrm{Hd}$ & 55 & 65 & 90 & \\
\hline 22 & $\mathrm{HC}$ & 60 & 70 & 95 & \\
\hline 23 & IP & 45 & 55 & 80 & \\
\hline 24 & $\mathrm{JM}$ & 50 & 60 & 85 & \\
\hline 25 & KA & 60 & 70 & 95 & \\
\hline 26 & LA & 50 & 60 & 85 & \\
\hline 27 & $\mathrm{Mh}$ & 45 & 55 & 80 & \\
\hline 28 & NS & 50 & 60 & 85 & \\
\hline 29 & NK & 40 & 50 & 75 & \\
\hline 30 & $\mathrm{Ok}$ & 55 & 65 & 90 & \\
\hline 31 & PS & 40 & 50 & 75 & \\
\hline 32 & $\mathrm{Zu}$ & 45 & 55 & 80 & \\
\hline
\end{tabular}




\begin{tabular}{|l|l|l|l|l|l|}
\hline Rata - Rata & 57,58 & 62,32 & 74,03 & \\
\hline
\end{tabular}

rkan tabel 1 di atas terlihat adanya peningkatan hasil belajar. Rata-rata hasil belajar meningkat mulai dari pra siklus yaitu 57,58. Pada siklus I, rata-rata hasil belajar 63,32 sedangkan siklus IImeningkat menjadi 74,03. Hasil belajar ini dapat dilihat pada grafik berikut ini.

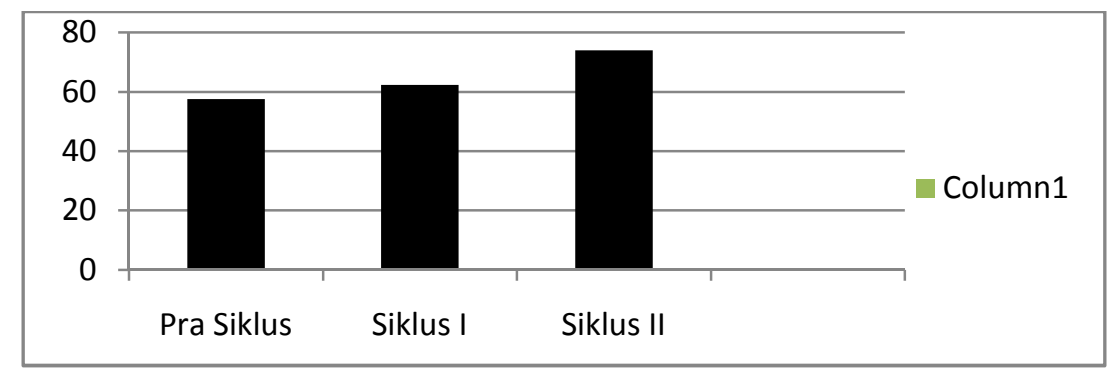

\section{Gambar 1}

\section{Rata-rata Hasil Belajar Siswa pada Pra Siklus, Siklus I, dan Siklus II;}

Analisis hasil evaluasi yang telah dilaksanakan, sebelum adanya perbaikan pembelajaran (pra siklus) tercatat 18 siswa dari 32 siswa yang mendapat nilai kurang dari 60 dengan nilai terendah 35 dan nilai rata-rata 57,58 . Namun setelah adanya perbaikan pembelajaran siklus I, siswa yang mencapai nilai 60 semakin bertambah dengan rata-rata kelas 62,32 pada siklus II siswa yang mencapai nilai diatas 60 semakin bertambah dengan ratarata kelas 74,03 .

b. Aktivitas Guru danSiswa dalam Pembelajaran

Aktivitas guru dan siswa dalam pelaksanaan pembelajaran pada pra siklus, siklus I, dan siklus II dapat dilihat pada tabel berikut.

Tabel 2

Prosentase Aktivitas Guru dan Siswa dalam Pembelajaran

\begin{tabular}{|l|l|l|l|l|l|l|}
\hline No & \multicolumn{1}{|c|}{ Aspek Yang Diamati } & Pra Siklus & Siklus I & Siklus II & \multicolumn{1}{|c|}{ Jml } & Rata2 \\
\hline \hline \multirow{2}{*}{1} & $\begin{array}{l}\text { Pra KBM } \\
\text { a. Berdo'a bersama }\end{array}$ & 100 & 100 & 100 & 300 & 100 \\
\cline { 2 - 7 } & b. Mengabsen siswa & 100 & 100 & 100 & 300 & 100 \\
\cline { 2 - 7 } 2 & $\begin{array}{l}\text { c. Menyiapkan aat - alat } \\
\text { Pelajaran }\end{array}$ & 80 & 80 & 80 & 240 & 80 \\
\hline & $\begin{array}{l}\text { Kegiatan Awal } \\
\text { Guru menanyakan informasi } \\
\text { yang mengarah pada materi } \\
\text { tentang anggota keluarga }\end{array}$ & 80 & 80 & 100 & 260 & 87 \\
\hline 3 & $\begin{array}{l}\text { Kegiatan Inti } \\
\text { a. Guru menjelaskan tentang } \\
\text { anggota keluarga }\end{array}$ & 60 & 80 & 100 & 240 & 80 \\
\hline
\end{tabular}




\begin{tabular}{|l|l|l|l|l|l|l|}
\multicolumn{2}{|l}{$\begin{array}{l}\text { membaca komik tentang peran } \\
\text { keluarga }\end{array}$} & 60 & 80 & 100 & 240 & 80 \\
\hline \multirow{4}{*}{4} & $\begin{array}{l}\text { Tanya jawab tentang komik } \\
\text { mg dibaca }\end{array}$ & 60 & 80 & 100 & 240 & 80 \\
\cline { 2 - 7 } & Siswa melakukan sosiodrama & 80 & 80 & 80 & 240 & 80 \\
\hline \multirow{5}{*}{5} & $\begin{array}{l}\text { Kegiatan Akhir } \\
\text { a. Saat menyimpulkan materi }\end{array}$ & 80 & 80 & 80 & 240 & 80 \\
\cline { 2 - 8 } & b. Saat mengerjakan tes akhir & 80 & 100 & 100 & 280 & 93 \\
\cline { 2 - 8 } & c. saat menganalisa hasil tes & 60 & 80 & 100 & 240 & 80 \\
\hline Jumlah & 840 & 940 & 1,040 & 2,820 & 940 \\
\hline Rata-rata & 76 & 85 & 95 & 256 & 85 \\
\hline
\end{tabular}

Grafik Prosentase Aktivitas guru dan Siswa pada Pra Siklus, Siklus I, dan Siklus II sebagai berikut.

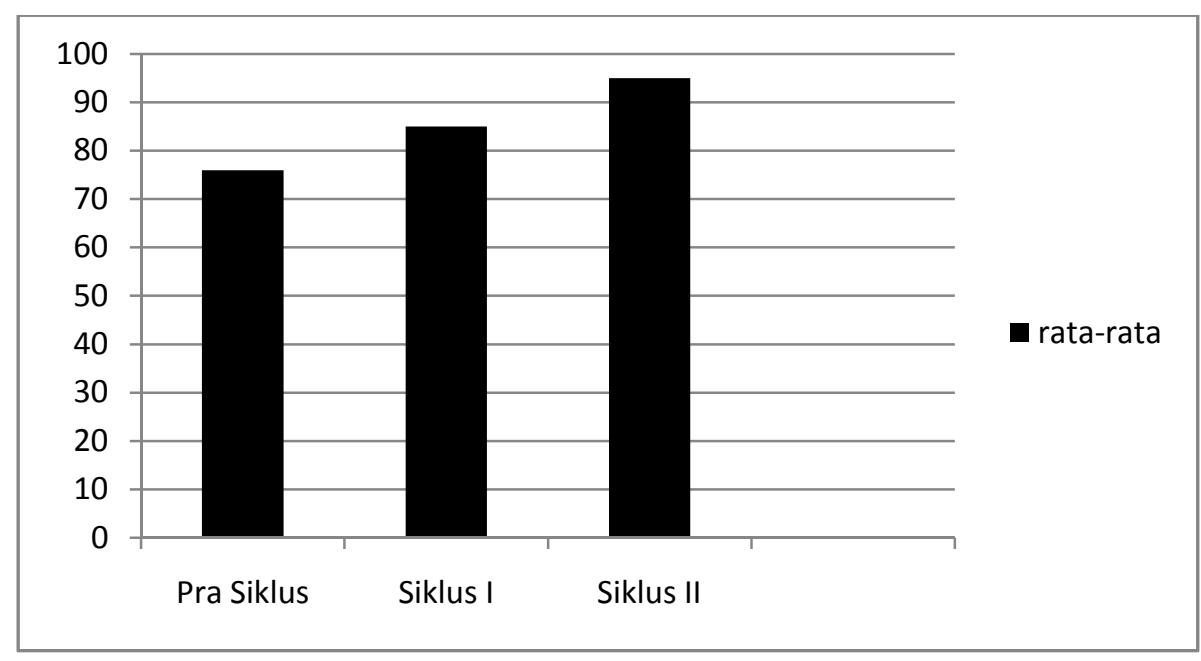

Gambar 2

Grafik Persentasi Aktivitas Guru dan Siswa

Hasil refleksi terhadap proses pembelajaran dan hasil observasi yang dilakukan pengamat tercatat bahwa sebelum diadakan perbaikan pembelajaran (pra siklus) Ilmu Pengetahuan sosial, tingkat kegairahan dan keberanian siswa tergolong rendah yaitu hanya $77 \%$. Aktifitas pembelajaran masih didominasi oleh guru. Namun setelah perbaikan pembelajaran siklus I, kegairahan dan keberanian siswa dalam pembelajaran meningkat menjadi $86 \%$ siswa terlihat aktif dan antusias dalam pembelajaran, $80 \%$ siswa menjawab pertanyaan guru, $80 \%$ siswa bertanggung jawab terhadap tugas yang diberikan guru. Pada siklus II siswa aktivitas siswa semakin bertambah menjadi $95 \%$.

\section{PEMBAHASAN}

Hasil penelitian ini menunjukkan bahwa pada mata pelajaran IPS dari 31 siswa masih banyak siswa yang mendapatkan nilai dibawah KKM (KKM yang ditetapkan 60) dengan prosentase sebagai berikut 0-59 sebanyak 17 anak (42,5 \%) dan 60-100 sebanyak 23 anak (57,5\%). Rendahnya prestasi belajar siswa pada pra siklus dikarenakan guru belum menggunakan metode pembelajaran yang tepat. 
Aktivitas belajar siswa masih tergolong rendah karena tingkat keaktifan siswa hanya 59\%. Rendahnya aktifitas siswa ini disebabkan karena guru belum menggunakan media pembelajaran yang tepat.Penggunaan media pembelajaran membuat pembelajaran lebih terfokus, perhatian siswa akan lebih tertuju pada media tersebut. Hal ini berarti meningkatkan aktivitas belajar siswa dan terutama mengurangi terjadinya verbalisme (salah penafsiran) terhadap bahan ajar yang disampaikan pada diri siswa.Media pembelajaran merupakan segala sesuatu yang dapat digunakan untuk merangsang pikiran, perasaan, perhatian dan kemauan anak didik sehingga dapat mendorong terjadinya proses belajar pada diri siswa(Dwidjiastuti:1997).

Data hasil penelitian diperoleh bahwa pada mata pelajaran IPS dari 31 siswa masih banyak juga siswa yang mendapatkan nilai dibawah KKM dengan prosentase sebagai berikut : 0-59 sebanyak 11 anak (27,5\%) dan 60-100 sebanyak 29 anak (72,5\%). Berdasarkan hasil penelitian diperoleh bahwa pada mata pelajaran IPS dari 31 siswa telah banyak siswa yang mendapatkan nilai diatas KKM dengan prosentase sebagai berikut : 0-59 \% sebanyak 3 anak (7,5\%) dan 60-100 sebanyak 37 anak (92,5\%), dalam hal ini pembelajaran dikatakan tuntas. Ketuntasan dalam pembelajaran IPS ini disebabkan karena guru sudah siap dalam menggunakan metode sosiodrama.Keberhasilan suatu pembelajaran selain ditunjang oleh penggunaan alat peraga/media, juga dipengaruhi penggunaan metode yang tepat.Aktivitas belajar, siswa banyak mengalami peningkatan yang signifikan yaitu dari pra siklus 59\%, siklus 74\% sedangkan siklus II-nya 92\%. Peningkatan aktivitas belajar ini dikarenakan guru siap dalam menggunakan media gambar komik.

\section{SIMPULAN DAN SARAN}

KESIMPULAN

Hasil penelitian dan pembahasan dapat disimpulkan sebagai berikut :

1. Metode Sosiodrama dapat meningkatkan hasil belajar. Hal ini dibuktikan dengan peningkatan hasil belajar siwa setiap siklus.

2. Media gambar komik dapat meningkatkan aktivitas belajar siswa.Hal ini ditunjukkan semakin banyaknya siswa terlibat dalam setiap pembelajaran.

\section{SARAN-SARAN}

Berdasarkan kesimpulan di atas, penulis memberi saran-saran sebagai berikut.

1. Teman-teman guru untuk dapat menggunakan metode sosiodrama dalam pembelajaran IPS. Agar siswa dapat memahami kondisi social.

2. Teman-teman guru dapat menggunakan media gambar komik sebagai media alternative untuk membantu siswa lebih aktif belajar.

3. Kepala UPPK agar memberikan motivasi kepada guru-guru untuk melakukan refleksi sehingga bila mengalami kegagalan dalam pembelajaran tidak selalu menyalahkan siswa.

4. Kepala Sekolah agar memberikan dukungan kepada guru-guru untuk melakukan refleksi sehingga tujuan pembelajaran dapat tercapai dengan baik.

\section{DAFTAR PUSTAKA}

Abu Ahmadi. 2005. Strategi Belajar Mengajar. Bandung: Pustaka Setia.

Arsyad, Ashar. 2002. Media Pembelajaran. Jakarta: PT Raja Grafindo Persada.

Wardani, IG. A. K. dkk (2007). Pemantapan Kemampuan Profesional (panduan). Pusat Penerbitan Univesitas Terbuka. Jakarta

Gatot Muhsetyo. Dkk (2007). Pembelajaran Matematika SD Jakarta Universitas Terbuka

Dwidjiastuti, dkk.(1997). Strategi Belajar Mengajar.D II. PGSD / Semester I, Surakarta, Universitas Sebelas Maret.

Wardani, IG, A.K. dkk (2004). Penelitian Tindakan Kelas Pusat Penerbitan Universitas Terbuka Jakarta.

Sugandi Achmad Drs. M.Pd, dkk (2004) Teori Pembelajaran, Semarang, UPT MKK UNNES

Herhyanto, Nar. Hamid H. M. Akib (2006). Statistika Dasar. Jakarta : Universitas Terbuka.

Ritawati, Mahyudin dan Yetti Ariani. 2007. Hand Out Mata Kuliah Metodologi Penelitian Tindakan Kelas. Padang: S1 PGSD FIP UNP.

Rochiati, Wiriaatmadja. 2007. Metode Penelitian Tindakan Kelas untuk Meningkatkan Kinerja Guru dan Dosen. Bandung: PT. Remaja Rosda Karya 